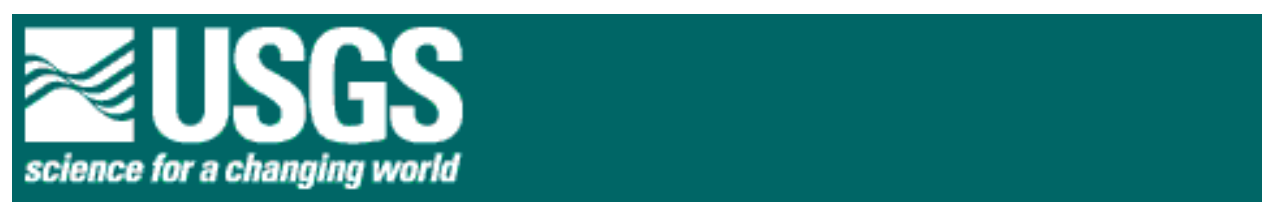

\title{
MAGNETOTELLURIC DATA ALONG THE TANGLE LAKES PROFILE, ALASKA
}

by Jay A. Sampson ${ }^{1}$, and Brian D. Rodriguez ${ }^{1}$

Open-File Report 02-0177

paper edition

2002

This report is preliminary and has not been reviewed for conformity with U.S. Geological Survey editorial standards or with the North American Stratigraphic code. Any use of trade, firm, or product names is for descriptive purposes only and does not imply endorsement by the U.S. Government.

\section{U.S. DEPARTMENT OF THE INTERIOR}

\section{U.S. GEOLOGICAL SURVEY}

${ }^{1}$ U.S. Geological Survey, Denver Federal Center, Box 25046, MS 964, Denver, Co 80225 
The $89 \mathrm{~km}$ long Tangle Lakes profile of 14 magnetotelluric (MT) stations begins $4 \mathrm{~km}$ south of the confluence of Augustana Creek and the Delta River in south central Alaska. The northernmost station, TLM13, is located just south of the Denali Fault in the rugged Clearwater Mountains. The north-south profile crosses the Ampitheater Mountains northwest of the Tangle Lakes area and continues until it terminates in the flatlands south of the Alphabet Hills. The profile intersects the Denali Highway $32 \mathrm{~km}$ west of Paxson.

Various rock assemblages and structural features are crossed by this profile. MT data obtained in this study in conjunction with magnetic and gravity data should help provide the following information:

1. An estimate of the thickness of the Nikolai basalts in the Amphitheater Syncline.

2. Whether or not the Fish Lake and Tangle ultramafic complexes join at depth or are at different stratigraphic horizons beneath the Amphitheater Mountains Syncline.

3. A determination if there is a deep rooted magmatic feeder or a sequence of sedimentary material beneath the Amphitheater Syncline.

4. The dip and orientation of the Rainy and Broxson Gulch thrust systems.

5. Identification of other structures along the profile. 